Vol. 9 No.2 July 2020

P-ISSN: 2301-9913, E-ISSN: 2597-9132

DOI: http://dx.doi.org/10.31000/globish.v7i2

\title{
THE INTERNALIZATION OF ASMAUL HUSNA VALUES THROUGH THE DEVELOPMENT OF "AUTHENTIC READING MATERIALS" AS AN EFFORT TO BUILD RELIGIOUS CHARACTERS
}

\author{
Niken Kencono Ungu \\ Faculty of Language and Literature Sains Alqur'an University \\ E-mail Correspondence: kenconounguniken@yahoo.co.id
}

ABSTRACT

This research is a report of Nation Character Education which has a purpose as an Effort to Build Religious Character. The author will try to overcome the moral degradation that occurs in students such as bullying, free promiscuity, rah-rah, hedonism by internalizing Asmaul Husna's values into reading courses by developing the learning of authentic reading materials. From here, religious character education will begin to be built.

The results of the research include several things. The most important result is a product called a reading textbook that has been internalized with Asmaul Husna's values. This book is the development of authentic reading materials adapted to the syllabus in the reading course being taken by students of the English Education program especially the students of 3 Semester.

The research methodology used in this research is Research and Development (R \& D) which will be elaborated qualitatively. After conducted this research, it showed that the book product of authentic reading materials which had been internalized with Asmaul Husna was an effective way to build the students' character as the effort to overcome the students' moral degradation. 85\% showed that students have a significant increase in their reading ability and also students continue to display increasingly improved behaviors after learning the Asmaul Husna values in their reading textbook.

Keywords: Internalization of values, Asmaul Husna, Authentic Reading Materials, Building Religious Character.

\section{INTRODUCTION}

Moral degradation has begun to plague college circles. Hedonism, extramarital sex, anarchism are a few cases that often occur later. Therefore, learning methods are needed that can build the religious character of students so that juvenile delinquency can gradually be overcome. One alternative is the development of authentic reading material internalizing the values of Asmaul Husna into the material. Why does it have to develop reading learning? Isn't it about learning listening, speaking, or writing? Because according to Donna D (2001) with reading learning students will be able to learn new vocabulary, new phrases, sentence constructs, and other skills which in turn are very important to support the development of other language competencies such as listening, writing, and speaking. Besides, reading will also make it easier for teachers to internalize the values that they want to instill in students. To make more meaningful and interesting reading learning, it is necessary for the lecturer's effort to provide reading learning as interesting as possible which can be done by developing "authentic materials". Because according to Martinez (2002), learning to read by developing authentic materials aims to provide an interesting learning experience because reading learning will be meaningful learning like real life. The next step is to internalize the values of Asmaul Husna into their learning. Internalization is defined as a process of deepening or appreciation. So it can be interpreted that internalization is a process of appreciation or as absorption of a developing value. Internalization can also be interpreted as the inclusion of value in someone who will shape his mindset in seeing the reality of experience. Asmaul Husna is the attributes of the majesty of God which amounted to 99. To glorify the quality of God should not only be pronounced on the lip but should enable us to emulate the qualities it contains. Therefore, authentic reading material is a way that can be implemented to conduct the values above to be 
Globish (An English-Indonesian journal for English, Education and Culture)

Vol. 9 No.2 July 2020

P-ISSN: 2301-9913, E-ISSN: 2597-9132

DOI: http://dx.doi.org/10.31000/globish.v7i2

an effective package of reading learning to build students' religious character and the development of that way to be a reading textbook is a very effective way to do.

\section{Internalization of values}

In scientific dictionaries (Arkola: 256), internalization is defined as the process of deepening or appreciation. So it can be interpreted that internalization is a process of appreciation or as absorption of a developing value. Internalization can also be interpreted as the inclusion of value in someone who will form the mindset in seeing the reality of experience.

In the Kamus Besar Bahasa Indonesia/ KBBI (A Large and Complete Indonesian Dictionary), Internalization is defined as appreciation, assignment, mastery in depth which takes place through coaching, guidance, counseling, upgrading, and so on. This can take place through counseling, upgrading, and so on is a belief and awareness of the truth of doctrines or values embodied in attitudes and behavior.

Internalization is appreciation, deepening, mastery in depth through guidance, guidance, and so on. Thus internalization is a process of instilling an attitude into one's self through coaching, guidance, and so on so that the ego deeply masters a value and lives so that it can be reflected in attitudes and behavior following expected standards.

So internalization is a deep process to live religious values combined with values.

In a psychological sense, internalization means the union of attitudes or incorporation, standards of behavior, opinions, in personality. Freud believed that the superego or the moral aspect of personality originated from the internalization of parental attitudes. There are three steps of the internalization process related to the students' coaching, namely:

1. Value transformation stage: This stage is a process carried out by educators in informing good values and good grades. At this stage, only verbal communication occurs between lecturer and student.

2. Value Transaction Stage: a stage of value education by way of two-way communication or interaction between students and educators who are reciprocal.

3. The transinternalisation stage is far deeper than the transaction stage. At this stage not only is it done by verbal communication but also mental attitude and personality.

So from the understanding of internalization that is associated with human development, that the internalization process must be following the tasks of development. Internalization is a central change in personality which is a critical dimension to human selfchange which has a personality meaning to the response that occurs in the process of forming human nature.

\section{Asmaul Husna}

According to the book Asmaul Husna Effect, the word Asmaul Husna comes from Arabic which is a combination of two words namely al-Asma 'and al-Husna. Al-Asma 'is a form of jama' of ismun which means name. While al-Husna is a form of mashdar of al-Ahsan which means good. 
Globish (An English-Indonesian journal for English, Education and Culture)

Vol. 9 No.2 July 2020

P-ISSN: 2301-9913, E-ISSN: 2597-9132

DOI: http://dx.doi.org/10.31000/globish.v7i2

According to M. Ali Chasan Umar, the understanding of Asmaul Husna are the names of the best and the greatest of God, which is following the attributes of God, which there are 99 names.

Asmaul Husna refers to the names, titles, as well as the beautiful and good qualities of Allah SWT. The term Asmaul Husna is also stated by Allah SWT in QS Thaha ayah 8 which means:

"He is God, there is no God who is entitled to be worshiped but He is. He has Asma'ul Husna (good names).

Allah SWT also says in QS Albaqara: 31 and Al A'raf verse 180, as follows:

"Belong to Allah, beautiful names, and ask Him by calling them names." (Surat al-A'raf: 180)

"He taught Adam all names. (Surat al-Baqarah: 31)

The values contained in the Asmaul Husna, which will be used in the internalization of values by developing authentic reading materials.

\section{Authentic Reading Materials Learning}

Steinberg, Donna D, and his friends (2001) state that reading is a form of communication the goal of which is the reception of information through written forms, so the teaching program, consequently, should direct itself to the realization of that goal. So it is why in teaching reading, the teacher should be careful in choosing the technique, making syllabus which is appropriate with the students' need, determining the aims, preparing the material and applying the technique during the reading class.

C. Nuttal (1996) says that teaching reading comprehension in a foreign language can be considered as a cycle that begins with the collections of information from an input. This can be turned by the students into either verbal summaries or non-verbal displays in the form of transition notes, and this, in turn, can be used to produce itself on verbalization of the information as students' output.

Based on the above explanation it can be defined that reading learning is learning that aims to communicate information in written form so that as a result the reading learning program must be able to directly realize these goals by itself.

According to Jack C. Richards (2002: 251) authentic materials refer to the use in the teaching of texts, photographs, video selection, and other teaching resources that are not specifically prepared for pedagogical purposes.

Meanwhile, Karen (2002) defines that it is considered desirable to allow learners to respond to genuine communications and understand language as actually used by native speakers.

Martinez (2002), reading learning by developing authentic materials aims to provide an interesting learning experience because reading learning will become meaningful learning like real life. 
Globish (An English-Indonesian journal for English, Education and Culture)

Vol. 9 No.2 July 2020

P-ISSN: 2301-9913, E-ISSN: 2597-9132

DOI: http://dx.doi.org/10.31000/globish.v7i2

Based on the explanation above it can be concluded that authentic material is material designed to provide learning and learning experiences for students as if they were being confronted with real-life like the original speaker. Therefore, it can aim to increase student motivation.

\section{Building Religious Character}

According to KBBI (Kamus Besar Bahasa Indonesia), the building is to improve, foster, enforce, cultivate, and enforce.

According to Muchlas Samani and Hariyanto in his book Concepts and Models of Character education, the character is the same as the moral in the Islamic view. Moral in the Islamic view is personality.

The basic word of religion is the religion that comes from a foreign language religion as a form of a noun which means religion or belief in the existence of something natural power over humans. While religious comes from the word religion which means the religious nature inherent in a person (Thontowi, 2013).

Broadly speaking, the title written by this author implies theoretically that an attempt of deepening and appreciation to improve, uphold, foster and foster by understanding, applying and realizing 99 attributes and names of the Noble God Almighty for students through written learning wherein the material inside is designed to provide students with learning and learning experiences as if they were being confronted with real-life like the original speaker.

\section{RESEARCH METHOD}

The research method that is used in this research is Research and Development / R\&D which will be elaborated qualitatively. This research method is used to produce certain products and test the effectiveness of the methods used. In the field of education, R\&D is a research method used to develop or validate products used in education and learning. So from the description above, it can be concluded that Research and Development is a research method that aims to produce certain products and test the validity and effectiveness of these products in their application. (http://www.aftanal.com).

Based on the Given (2008) qualitative approach is typically used to explore the new phenomena and to capture an individual's thoughts, feelings, or interpretations of meaning and process (p.29)

Researchers conducted this research on the third semester of English language education students at the Universitas Sains Al-Qur' an, located on Kalibeber Street, km.3, Mojotengah District, Wonosobo, Central Java. The research began in January-June 2019 and was participated by 31 participants, 10 were male students and 21 were female students.

The steps of the research to internalize the Asmaul Husna values by developing Authentic Reading material are as follows:

1. Determine the material to be taught for one semester. The material is taken from the syllabus of the reading course. 
Globish (An English-Indonesian journal for English, Education and Culture)

Vol. 9 No.2 July 2020

P-ISSN: 2301-9913, E-ISSN: 2597-9132

DOI: http://dx.doi.org/10.31000/globish.v7i2

2. Developing the values in Asmaul Husna, which will be used to build the religious character of students.

3. The validation process I by Islamic Lecturers (Validation I relates to the values of Asmaul Husna that have been developed by the author so as not to deviate from the order of interpretation of the Qur'an and Al-Hadith).

4. To internalize Asmaul Husna values that have been validated by experts into authentic reading material. One material can consist of several character values that exist in Asmaul Husna. The character values were to be instilled in students during the material.

5. The creation of a textbook for the implementation of Asmaul Husna Values complemented by a summary of Authentic reading materials that have been internalized with Asmaul Husna values.

6. Validation Process II, by reading expertise. The task is to validate authentic reading materials that have been internalized with Asmaul Husna's values so as not to come out of pedagogical or linguistic principles.

7. Make RPS by using authentic reading materials that have been internalized with Asmaul Husna. The making of this RPS is very functional so that the learning that will be carried out later is following what was previously planned.

8. The final validation process by Islamic religious expertise on the results of authentic reading learning that has been internalized with the values of Asmaul Husna.

9. Internalization of Asmaul Husna's values into reading learning began.

10. Religious Character Students gradually begin to form and juvenile delinquency can be overcome slowly but surely and manifestly.

\section{RESEARCH FINDING AND DISCUSSION}

In this study, the authors found several findings of the use and effectiveness of the use of authentic reading materials that have been internalized with Asmaul Husna.

1. This method can be used as an alternative to making learning and teaching that internalize religious values, especially Asmaul Husna, to build and shape the religious character of students.

2. $85 \%$ of participants or 27 students were more conditioned in reading courses when learning begins with dhikr Asmaul Husna. Because the class had been conducive so the learning process will be able to run as expected.

3. $75 \%$ of the vocabulary skills of students increased. Because authentic learning reading material offered a new vocabulary for students who were never met every day.

4. $90 \%$ of students were stimulated in practicing the Asmaul Husna dhikr at home because this habit was always done before the reading course took place.

5. $85 \%$ of students were motivated to read a reading textbook of authentic materials that have been internalized with Asmaul Husna. Because this book product was packaged in such a way that students did not feel if they were learning to read. This automatically increased the ability to read and understand reading information because students always practice for scamming and scanning when reading.

The implementation of character education by internalizing Asmaul Husna's values through the development of authentic reading materials in the classroom can trace as 
Vol. 9 No.2 July 2020

P-ISSN: 2301-9913, E-ISSN: 2597-9132

DOI: http://dx.doi.org/10.31000/globish.v7i2

described in the learning plan that has been designed and developed by the researcher. The researcher will briefly describe as follows:

1. Learning began with chanting Asmaul Husna dhikr for 3 minutes. Besides this, it is also very useful to condition students to be calmer in initiating learning.

2. Furthermore, lecturers motivated students by starting to internalize the values that exist in Asmaul Husna. For example, the 4 character values to be internalized in asking attention in the reading session were as follows:

1) Al Hamiid: I want to always be commendable.

2) As Saami ': I want to always listen and understand others.

3) Al Baashir: I want to always see and pay attention to others.

4) Al Lathiif: I want to always be gentle with people and feel the feelings of others.

3. After the values were internalized to students, the researcher gave brainstorming questions following the theme to be discussed. For example:

1) What do you feel when delivered attention to others?

2) How do you say attention?

3) Why do you have to pay attention?

4) What is your intention when deliver attention? Do you hope for some compliments?

5) What the characters must be involved when you asked attention to someone?

4. Next, the researcher described the learning objectives and material competence and values of Asmaul Husna to be achieved

5. The researcher instructed to open the book authentic materials.

6. Learning Authentic reading material took place. Students discussed in groups about the reading offered in the book. They discussed both the content and the religious values contained therein.

7. Before the lecture was closed, feedback on the learning that has been done must be carried out. It aims to make students more enthusiastic for the next reading. For example: Thank you very much for your participation. You did a good job, I'm very happy with your activity in the class. How about you, did you enjoy my class?

8. The closing activity was carried out by stimulating students to conclude the day's learning and concluded the religious character values that have been described so that students easily applied them in everyday life. After that, the researcher used to remind the students to practice the dhikr of Asmaul Husna at home.

The Obstacles Faced with the Internalization of Asmaul Husna's Values in authentic reading materials either inside, outside the classroom, or in society were as follows:

1. Students had difficulty in understanding authentic reading materials that have been internalized with the values of Asmaul Husna. So if they did not bring a dictionary, it was a significant obstacle to achieving the expected competence.

2. Students had difficulty in understanding the authentic reading text because students do not understand the contents of reading both grammatically and lexically. This caused the discussion process to be quite long. If the teacher did not go down directly, then the competency to be achieved to develop religious character will not be achieved.

3. The lecturer lacked time in implementing authentic reading materials that were internalized with Asmaul Husna's values in the classroom, allocations were only $2 \mathrm{x}$ 45 minutes, making lecturers have to rack their brains so that all aspects and 
Globish (An English-Indonesian journal for English, Education and Culture)

Vol. 9 No.2 July 2020

P-ISSN: 2301-9913, E-ISSN: 2597-9132

DOI: http://dx.doi.org/10.31000/globish.v7i2

components in this learning can be properly covered according to with the allocation of time provided.

4. The internalization material presented was less interesting or not suitable for the psychological condition of students. This caused the failure to internalize Asmaul Husna's values into students.

Supporting Factors in Overcoming Constraints

To overcome the obstacles as described above, several supporting factors must be prepared carefully. The supporting factors are as follows:

1. Skimming and scanning strategies need to be introduced and taught more deeply to students. This can help the difficulties of those who translate an authentic text verbally. With these two techniques, it is hoped that students can capture the information conveyed by authentic reading materials made by the author. Where the information in it is loaded with the internalization of Asmaul Husna's values which are useful for building students' religious character.

2. Lecturers must be more creative and innovative in making the material of Asmaul Husna's internalized values more interesting and following the experiences and conditions of students' religious character so that they remain enthusiastic during the lecture.

3. Lecturers must understand the concept of the internalization of Asmaul Husna in greater detail. So that at the time of presentation they can convince and stimulate students to internalize "Asmaul Husna values" in all aspects of life. Regardless of Muslims and Non-Muslims, the essence of Asmaul Husna's values is universal.

\section{CLOSING}

Internalizing Asmaul Husna's values with the development of "Authentic Reading Materials" is very effective in building religious character. This process will develop and produce a reading book that contains various values contained in Asmaul Husna. It is also very effective in overcoming moral degradation that occurs among English language education students.

With this book product produced through research and development research, 85\% of students experience the ability to understand reading texts well because students are always encouraged to always read them by scanning and scamming before the discussion process begins. The remaining 15\% still have difficulty in reading texts because they are unfamiliar with the vocabulary found in the readings and they are not yet familiar with the techniques of reading by scamming and scanning which are carried out before the discussion process takes place.

\section{REFERENCES}

Abdurrahim, Sulaiman \& Abu Fawaz. 2009. Asmaul Husna Effects. Bandung. Arkanleema.

Bahasa Inggris SMA/MA/SMk/MAK kelas XI semester 1. 2014. Pusat Kurikulum dan perbukuan, Balitbang, Kemendikbud. 
Globish (An English-Indonesian journal for English, Education and Culture)

Vol. 9 No.2 July 2020

P-ISSN: 2301-9913, E-ISSN: 2597-9132

DOI: http://dx.doi.org/10.31000/globish.v7i2

Given,L.M. (2008). The SAGE Encyclopedia of Qualitative Research Methods. Los Angeles; SAGE Publication Inc.

James Caplin, Kamus Lengkap Psikologi, (Jakarta: PT Raja Grafindo Persada, 1993), h. 256

Karen. 2002. Authentic Materials on Overview. http:// www.google.com, August 22, 2016

Kementrian Pendidikan dan Kebudayaan. 2014. Materi pelatihan Guru Implementasi Kurikulum 2013 Mata Pelajaran Bahasa Inggris SMA/SMK. Jakarta: Pusat Pengembangan Profesi Pendidik Badan Pengembangan Sumber daya Manusia Pendidikan dan Kebudayaan Penjaminan Mutu Pendidikan kementrian Pendidikan dan Kebudayaan

Martinez, A.G. (2000). Authentic Materials in Overview. Retrieved july 6, 2016 from http//: www3Telus.net/-linguisticissues/authenticmaterials.htm.

Nuttal, C. (1996). Teaching Reading Skills in a Foreign Language (New Edition). Oxford: Heinemann.

Pusat Pembinaan dan Pengembangan Bahasa Departement Pendidikan dan Kebudayaan, Kamus Besar Bahasa Indonesia, (Jakarta: Balai Pustaka, 1989) P.336

Richards, Jack C. 2002. Curriculum Development in Language Teaching (Authentic Materials). Cambridge: Cambridge University Press.

Samani, Muchalas dan Haryanto. 2011. Pendidikan Karakter: Konsep dan Modal. Bandung: PT Remaja Rosdakarya.

Steinberg, Donna, D and his friends (2001). Using Reading Comprehension. Oxford: Blackwell.

Thontowi, A. 2012. Hakekat Religusitas. (Online) (http://www.sumsel.kemenag.go.id, accessed at June 15, 2020. 